\title{
Toxicity of peracetic acid (PAA) to tomonts of Ichthyophthirius multifiliis
}

\author{
T. Meinelt ${ }^{1, *}$, S. Matzke ${ }^{2}$, A. Stüber ${ }^{1}$, M. Pietrock ${ }^{3}$, A. Wienke ${ }^{4}$, A. J. Mitchell ${ }^{5}$, \\ D. L. Straus ${ }^{5}$ \\ ${ }^{1}$ Leibniz-Institute of Freshwater Ecology and Inland Fisheries, Mueggelseedamm 301, 12587 Berlin, Germany \\ ${ }^{2}$ Humboldt-University of Berlin, Invalidenstr. 42, 10115 Berlin, Germany \\ ${ }^{3}$ Toxicology Centre, University of Saskatchewan, 44 Campus Drive, Saskatoon, Saskatchewan S7N 5B3, Canada \\ ${ }^{4}$ Martin-Luther-University Halle-Wittenberg Medical Faculty Institute of Medical Epidemiology, Biostatistics and \\ Informatics, Magdeburger Strasse 27, 06097 Halle (Saale), Germany
}

${ }^{5}$ US Department of Agriculture, Agricultural Research Service, Harry K. Dupree Stuttgart National Aquaculture Research Center, PO Box 1050, Stuttgart, Arkansas 72160, USA

\begin{abstract}
The free-living infective theront of Ichthyophthirius multifiliis historically has been thought to be the only stage susceptible to treatment. Here we introduce a technique to determine the toxicity of compounds to the newly released tomont, the encysted tomont and the developing tomites within the tomont that emerge as theronts. The toxicity of Wofasteril ${ }^{\circledR} \mathrm{E} 400(40 \%$ peracetic acid, PAA) to free-living forms of $I$. multifiliis was determined shortly after tomonts were physically removed from the surface of the fish and at 2.5 and $24 \mathrm{~h}$ after removal. Results indicate that 0.6 to $0.9 \mathrm{mg} \mathrm{l}^{-1}$ PAA killed 39 to $82 \%$ of the newly released tomonts within $48 \mathrm{~h}$ when treated immediately. In a second experiment, tomonts were allowed to settle for $2.5 \mathrm{~h}$ after sampling from the skin and then treated for $12 \mathrm{~h}$; concentrations $\geq 0.5 \mathrm{mg} \mathrm{l}^{-1}$ PAA produced significantly fewer theronts than the controls. In a third experiment, encysted tomonts that were exposed to PAA $24 \mathrm{~h}$ after sampling from the skin and treated for 2 or $4 \mathrm{~h}$ produced a variable amount of theronts, but the concentrations tested $(0.5$ to $3.0 \mathrm{mg} \mathrm{l}^{-1}$ ) did not halt theront production. This research demonstrates that encysted I. multifiliis are less susceptible to chemical treatments.
\end{abstract}

KEY WORDS: Ichthyophthirius multifiliis $\cdot$ Peracetic acid $\cdot$ Toxicity $\cdot$ Wofasteril ${ }^{\circledR}$

\section{INTRODUCTION}

Ichthyophthirius multifiliis (Fouquet) is the causal agent of white spot disease, or Ich, and is one of the most detrimental parasites in ornamental fish culture and other types of aquaculture around the world. The life cycle of this ciliated protozoan has 3 morphologically distinct stages. Upon entering the skin and gills, the non-feeding (lacking a cytostome), free-swimming theront transforms into a trophont, which feeds on mucus and tissue. The trophont grows within the skin tissue for several days depending on ambient temperatures. The mature trophont leaves the host, attaches to a solid surface and is called a tomont. The encysted tomont undergoes a series of divisions over a short period of time (dependent on temperature), resulting in tomites that break through the cyst wall to become theronts (Beckert \& Allison 1964, Nigrelli et al. 1976, Schäperclaus 1991, Lom \& Dyková 1992, Matthews 2005).

In the past, malachite green was used to treat Ichthyophthirius multifiliis infestations by killing the infective theronts (Amlacher 1961, Wahli et al. 1993). Amlacher (1961) suggested that malachite green was effective against both the free-living and intradermal stages; however, Wahli et al. (1993) suggested that the compound may irritate the interdermal stage, causing the parasite to exit the fish and then become susceptible to the chemical. Because of its carcinogenic potential, malachite green was banned as a therapeutant in 
EU member states, the United States and numerous other countries for the treatment of fish meant for human consumption, but not necessarily for ornamentals. The search for alternative treatments for $I$. multifiliis has been accelerated over the past decade. A method was developed to determine the toxicity of potassium permanganate to $I$. multifiliis theronts (Straus \& Griffin 2001) and has also been used to screen other chemicals such as copper sulphate (Goodwin \& Straus 2006) and peracetic acid (PAA; Meinelt et al. 2007a, Straus \& Meinelt 2009).

Schäperclaus (1991) used Wofasteril ${ }^{\circledR}$ as a disinfectant when working with diseased fish. Wofasteril ${ }^{\circledR}$ is widely used in agriculture and has recently been recommended as an alternative parasiticide to malachite green to treat external parasites (Meinelt et al. 2007b). Wofasteril ${ }^{\circledR}$ E400 contains 40 g PAA, 15 g hydrogen peroxide and $25 \mathrm{~g}$ acetic acid in $100 \mathrm{ml}$ solution. In addition to having a broad antimicrobial spectrum, PAA does not contribute to the formation of resistance. Even at low concentrations, Kitis (2004) found antimicrobial effects of PAA. Several studies (Meinelt et al. $2004,2005,2006$ ) have documented the effects of PAA against the parasitic water mould Saprolegnia parasitica and against various other fungal infections on fish and fish eggs.

Treatment of an Ichthyophthirius multifiliis infestation with PAA is effective on theronts that are not protected by the fish mucus and skin. Meinelt et al. (2007a) determined that $0.3 \mathrm{mg} \mathrm{l}^{-1}$ PAA reduced the number of free-living theronts by $24 \%$ when compared to the controls 5 min after exposure. Concentrations of $0.5 \mathrm{mg} \mathrm{l}^{-1}$ PAA killed all free-living theronts within 9 min. Rintamäki-Kinnunen et al. $(2005 a, b)$ treated $I$. multifiliis in ponds and concrete raceways with mixtures of PAA-products and formalin and reduced the abundance of the parasite in fish. However, nothing is known about the toxicity of PAA to trophonts, tomonts or tomites within the tomont, which are protected from adverse environmental conditions by the cyst wall during development (Ewing et al. 1983).

The purpose of these investigations was to determine the toxicity of PAA to recently released Ichthyophthirius multifiliis tomonts and to determine the effect of time after removal from the fish skin until parasite encystment on PAA toxicity.

\section{MATERIALS AND METHODS}

The chemical treatment used in this study (Wofasteril ${ }^{\circledR}$ E400) was obtained from KESLA PHARMA WOLFEN. Reconstituted water prepared according to DIN EN ISO 7346-3 (International Organization for
Standardization 1996) was used in all tests and Ichthyophthirius multifiliis cultures. The water consisted of $294.0 \mathrm{mg} \mathrm{l}^{-1} \mathrm{CaCl}_{2} \cdot 2 \mathrm{H}_{2} \mathrm{O}, 123.3 \mathrm{mg} \mathrm{l}^{-1}$ $\mathrm{MgSO}_{4} \cdot 7 \mathrm{H}_{2} \mathrm{O}, 63.0 \mathrm{mg} \mathrm{l}^{-1} \mathrm{NaHCO}_{3}$ and $5.5 \mathrm{mg} \mathrm{l}^{-1} \mathrm{KCl}$ dissolved in deionised water. Consequently, the reconstituted water contained $2 \mathrm{mmol} \mathrm{l}{ }^{-1} \mathrm{Ca}^{2+}, 0.5 \mathrm{mmol} \mathrm{l} \mathrm{l}^{-1}$ $\mathrm{Mg}^{2+}, 0.077 \mathrm{mmol} \mathrm{l}^{-1} \mathrm{~K}^{+}$and $0.77 \mathrm{mmol} \mathrm{l}^{-1} \mathrm{Na}^{+}$. Dissolved oxygen was $7.2 \pm 0.5 \mathrm{mg} \mathrm{l}^{-1}$ ( 74\% saturation), pH ranged between 7.5 and 8.0 and water temperature was maintained at $15^{\circ} \mathrm{C}$.

Stages of Ichthyophthirius multifiliis used in the experiments. I. multifiliis was obtained from infected goldfish Carassius auratus (L.) sampled at various commercial fish hatcheries outside Berlin, Germany. Fully developed trophonts (as determined by relative size) were gently scraped from the skin of the fish with a spatula into crystallising dishes (Carl Roth C095.1) containing reconstituted water. The tomonts were rinsed several times to remove mucus or tissue in the dishes. The I. multifiliis stages that were subjected to treatment included: (1) tomonts removed from fish by scraping and immediately used in experiments; (2) tomonts removed from the fish and allowed to settle for $2.5 \mathrm{~h}$ before being used in experiments; (3) tomonts removed from the fish and allowed to settle for $24 \mathrm{~h}$ before being used in experiments. Theronts that were produced from the tomonts were used as a measure of tomont survival in Expts 2 \& 3 .

Toxicity of PAA to unsettled tomonts. In the initial experiment, effective concentrations were determined. The concentrations of PAA in this experiment ranged from 0.1 to $0.9 \mathrm{mg} \mathrm{l}^{-1}$ (in $0.1 \mathrm{mg} \mathrm{l}^{-1}$ increments) and a negative control. There were 36 tomonts individually exposed to each concentration of PAA $(n=36)$. One tomont was transferred along with $100 \mu$ l of reconstituted water into each well of a 24 -well plate $\left(\right.$ Cellstar ${ }^{\circledR}$ 662160, Greiner Bio-One) that contained $900 \mu \mathrm{l}$ of tempered reconstituted water. Next, $1 \mathrm{ml}$ of each PAA stock solution was applied to give the appropriate final concentration. In the controls, $1 \mathrm{ml}$ of reconstituted water without PAA was applied. The solutions were not changed throughout the $48 \mathrm{~h}$ experiment. The $24-$ well plates were stored in an incubator at $15^{\circ} \mathrm{C}$. At 48 h, an Olympus IMT-2 inverse-microscope was used to determine if the tomonts had encysted and were dead or alive. Tomonts were considered dead if their nucleus was invisible or not horseshoe-shaped (coagulated) and cilia movement was not detected.

Toxicity of PAA to tomonts allowed to settle for $2.5 \mathrm{~h}$. In the second experiment, Ichthyophthirius multifiliis tomonts were obtained from infected goldfish and rinsed as described above. A $10 \mathrm{ml}$ aliquot of a gently stirred suspension was transferred into each of 14 crystallising dishes; the mean concentration of this suspension was 11.2 tomonts $\mathrm{ml}^{-1}$. The tomonts were 
allowed to settle for $2.5 \mathrm{~h}$ and were then exposed to a final concentration of $0.5,1,2$ or $3 \mathrm{mg} \mathrm{l}^{-1}$ PAA by adding $10 \mathrm{ml}$ of the respective PAA solution to the test dishes. There were 3 replications of each concentration, and 2 dishes without PAA served as negative controls. The crystallising dishes were incubated at $15^{\circ} \mathrm{C}$. At $12 \mathrm{~h}$ after exposure, the test solution was replaced by tempered test water.

After a total of $48 \mathrm{~h}$ of incubation, any theronts that had emerged from tomonts were fixed and counted. For this purpose, eight $100 \mu \mathrm{l}$ samples from each dish were transferred to a 96-well plate (BD Primaria ${ }^{\mathrm{TM}}$ 353872, Becton Dickinson Labware) and fixed with $100 \mu \mathrm{l}$ of $4.5 \%$ buffered formalin. The fixed theronts were allowed to accumulate at the bottom of the well for $2 \mathrm{~h}$ and counted with an inverse microscope.

Toxicity of PAA to tomonts allowed to settle for $24 \mathbf{h}$. In the third experiment, tomonts were collected as in the second experiment; the mean concentration of this suspension was 5.8 tomonts $\mathrm{ml}^{-1}$. Freshly recovered tomonts were allowed to attach to the bottom of the crystallising dishes for $24 \mathrm{~h}$. After the $24 \mathrm{~h}$ settling period, a subset of 3 replicates was exposed to $0.5,1,2$, 2.5 or $3 \mathrm{mg} \mathrm{l}^{-1}$ PAA for $2 \mathrm{~h}$. A second subset of 3 replicates was exposed to the same concentrations for $4 \mathrm{~h}$ with the exception of the $3 \mathrm{mg} \mathrm{l}^{-1}$ treatment; the latter concentration was not used because of lack of tomonts. After a total of $48 \mathrm{~h}$ of incubation, any theronts that had emerged from tomonts were fixed and counted.

Statistical analysis. For the test with unsettled Ichthyophthirius multifiliis tomonts, the lethal concentration $\left(\mathrm{LC}_{50}\right)$ and the $95 \%$ confidence interval (CI) were calculated by Probit analysis. In the experiment where the tomonts were allowed to settle for $2.5 \mathrm{~h}$, an independent $t$-test was used to determine significance between PAA-exposed groups and control. In the experiment where the tomonts were allowed to settle for $24 \mathrm{~h}$, the numbers of live and dead theronts in each treatment were compared by applying an analysis of variance (ANOVA). When there were overall differences between the groups, pairwise differences were analysed by means of the Dunnett T3 test. Differences were considered significant at $\mathrm{p}<0.05$. All analyses were performed using the Statistical Package for the Social Sciences software (SPSS for Windows, release 14.0)

\section{RESULTS}

Toxicity of PAA to unsettled tomonts. Preliminary experiments indicated that $1 \mathrm{mg} \mathrm{l}^{-1}$ PAA resulted in $90 \%$ mortality of the tomonts, and concentrations of $\geq 2 \mathrm{mg} \mathrm{l}^{-1}$ PAA resulted in $100 \%$ mortality of the exposed individuals within $48 \mathrm{~h}$. The 0.1 to $0.3 \mathrm{mg} \mathrm{l}^{-1}$
PAA treatments demonstrated little or no toxicity. At 0.4 and $0.5 \mathrm{mg} \mathrm{l}^{-1}$ PAA, there was 21 and $20 \%$ mortality by $48 \mathrm{~h}$, respectively (Fig. 1). From 0.6 to $0.9 \mathrm{mg} \mathrm{l}^{-1}$ PAA, Ichthyophthirius multifiliis mortality at $48 \mathrm{~h}$ increased from 39 to $82 \%$. In the controls, $100 \%$ of the tomonts became encysted and had started cleavage by $48 \mathrm{~h}$. The $48 \mathrm{~h} \mathrm{LC}_{50}$ was $0.68 \mathrm{mg} \mathrm{l}^{-1} \mathrm{PAA}$ (95\% CI = 0.59 to $0.79 \mathrm{mg} \mathrm{l}^{-1}$ ).

Although the exposure lasted $48 \mathrm{~h}$, lethal effects of PAA could be observed after $20 \mathrm{~min}$. During microscopic examination, dead tomonts were typically darker than live ones due to the initiation of necrotic coagulation (Fig. 2). Additionally, dead tomonts had lysed cell membranes, no signs of division and no cilia movement. In contrast, most live tomonts had become encysted, underwent division or had released theronts.

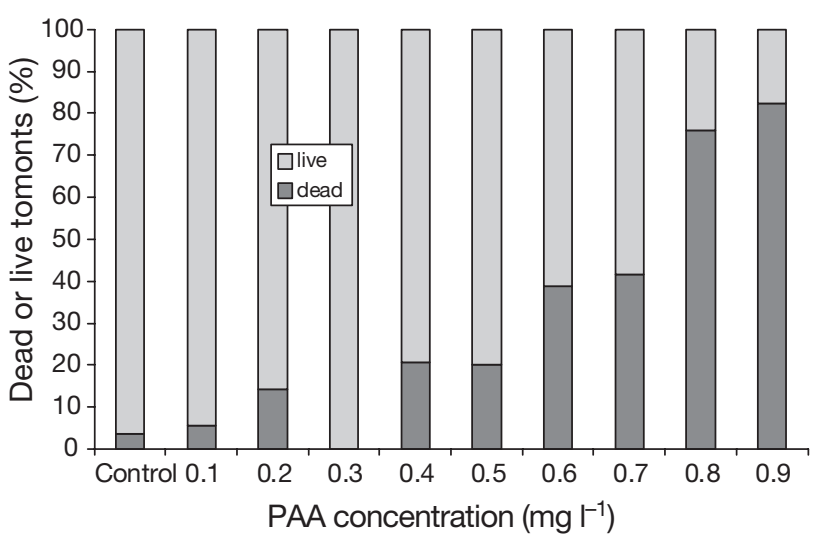

Fig. 1. Ichthyophthirius multifiliis. Dose-response relationship between percent of dead and live trophonts or tomonts in the detached trophont toxicity experiment after $48 \mathrm{~h}$ exposure to peracetic acid (PAA)

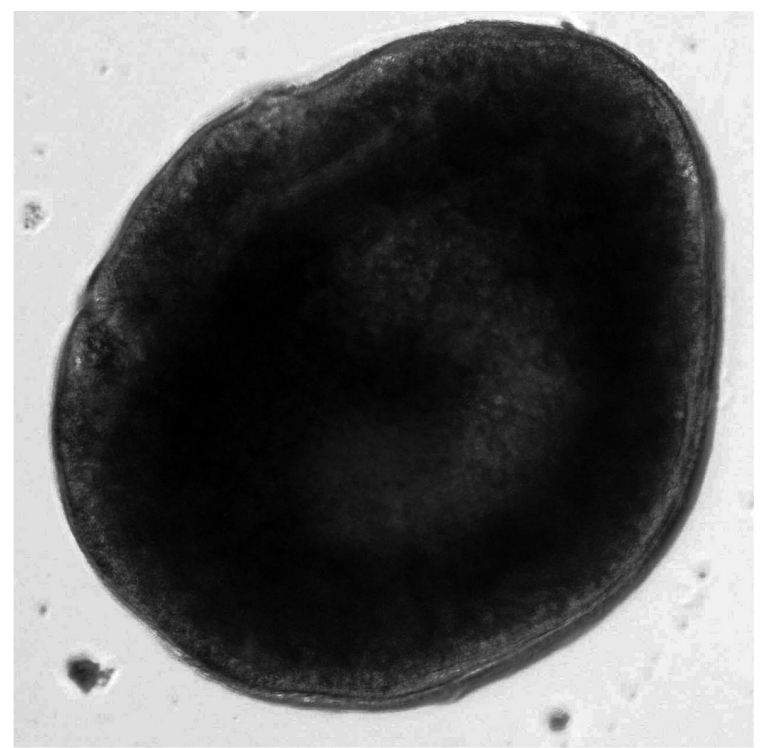

Fig. 2. Ichthyophthirius multifiliis. Coagulating tomont after peracetic acid (PAA)-treatment (400× magnification) 
Non-coagulated tomonts were counted as vital, even if they neither encysted nor produced any live theronts.

Toxicity of PAA to tomonts allowed to settle for $2.5 \mathrm{~h}$. After $48 \mathrm{~h}$ of incubation, the control produced $580 \pm 190$ theronts $\mathrm{ml}^{-1}$ (mean $\pm \mathrm{SD}$ ). The application of $0.5 \mathrm{mg} \mathrm{l}^{-1}$ PAA significantly $(\mathrm{p}<0.05)$ reduced the mean theront number to $58 \%$ of the control. Exposure to $1 \mathrm{mg} \mathrm{l}^{-1}$ PAA reduced the mean theront number to $25 \%$ of the control, while exposure to $2 \mathrm{mg} \mathrm{l}^{-1}$ PAA reduced the mean theront number to $2 \%$ of the control (Fig. 3). Applying $3 \mathrm{mg} \mathrm{l}^{-1}$ PAA resulted in $>99 \%$ mortality of the exposed tomonts (only 1 theront in 1 well survived).

Toxicity of PAA to tomonts allowed to settle for 24 h. Significant differences were observed between controls and Ichthyophthirius multifiliis tomonts exposed to PAA for 2 or $4 \mathrm{~h}(\mathrm{p}<0.05)$, respectively, except for the exposure to $0.5 \mathrm{mg}^{-1}$ for $4 \mathrm{~h}(\mathrm{p}=0.157)$. However, differences were not correlated to PAA concentration or to duration of application (Fig. 4). After $48 \mathrm{~h}$ incubations, all treatments showed live theronts. The theront number differed in all treatments independent of PAA-concentration and duration of the application. Tomont cell division and appearance of the protective cyst wall were evident at $24 \mathrm{~h}$.

\section{DISCUSSION}

Preliminary investigations were designed to determine the toxic PAA concentration to Ichthyophthirius multifiliis tomonts. Results demonstrated that the PAA product tested in this study (Wofasteril ${ }^{\circledR}$ E400) is acutely toxic, with concentrations $\geq 2 \mathrm{mg} \mathrm{l}^{-1}$ resulting in $100 \%$ mortality of the tomonts within $48 \mathrm{~h}$. Although the exposure lasted $48 \mathrm{~h}$, lethal effects of PAA could be observed after $20 \mathrm{~min}$.

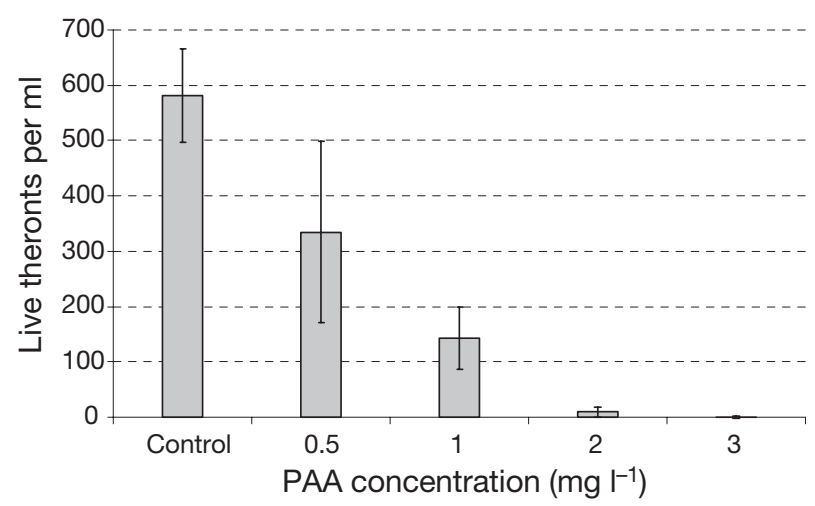

Fig. 3. Ichthyophthirius multifiliis. Mean number of live theronts $( \pm \mathrm{SD})$ produced from trophonts allowed to settle $2.5 \mathrm{~h}$ and then exposed to $0,0.5,1,2$ or $3 \mathrm{mg} \mathrm{l}^{-1}$ peracetic acid (PAA) for $12 \mathrm{~h}$. Total incubation time was $48 \mathrm{~h}$. All exposed groups are significantly different from the control $(p<0.05)$

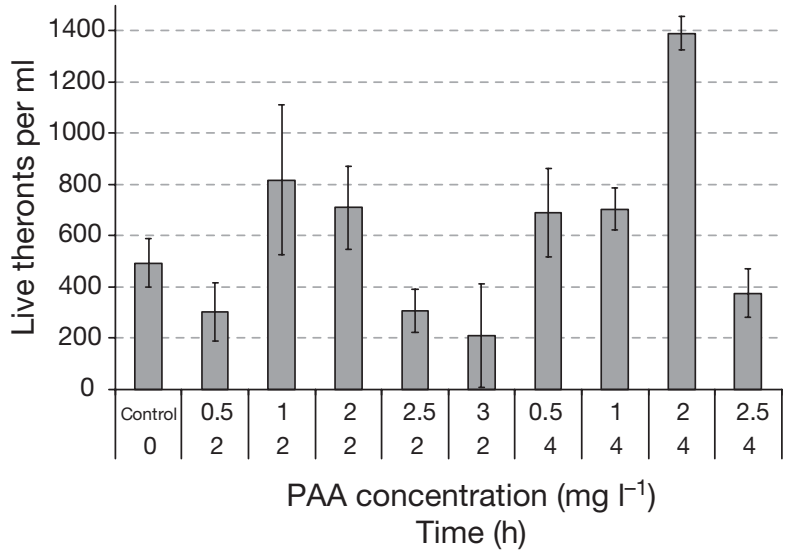

Fig. 4. Ichthyophthirius multifiliis. Mean number of live theronts $( \pm$ SD) produced from trophonts allowed to settle $24 \mathrm{~h}$ and then exposed to $0,0.5,1,2,2.5$ or $3 \mathrm{mg} \mathrm{l}^{-1}$ peracetic acid (PAA) for 2 or $4 \mathrm{~h}$. Total incubation time was $48 \mathrm{~h}$

In the first experiment, the range of PAA concentrations (Fig. 1) demonstrated a distinct dose-response relationship. At the end of the tomont experiment, the only evaluations made were whether the tomonts had encysted, whether they had survived exposure or whether they had died and were not intact. Due to the test design, it was not possible to draw reliable conclusions about the vitality and/or infectivity of theronts produced by surviving tomonts. Therefore, the number of theronts produced, as well as their vitality, was included in the test design of the following experiments.

MacLennan (1937) described a time interval of $2.5 \mathrm{~h}$ at $26^{\circ} \mathrm{C}$ for tomonts leaving the host until the beginning of encystment. According to Matthews (2005), Ichthyophthirius multifiliis tomonts encyst within a period of $15 \mathrm{~min}$ to $6 \mathrm{~h}$ after leaving the host. In the second experiment of the present study, PAA exposure was initiated $2.5 \mathrm{~h}$ after scraping the trophonts from the fish at $15^{\circ} \mathrm{C}$. During this period, most of the tomonts had already settled in the crystallising dishes and were possibly starting to encyst. A $12 \mathrm{~h}$ exposure to $0.5 \mathrm{mg}$ $\mathrm{l}^{-1}$ PAA reduced the mean number of theronts to $58 \%$ of the control (Fig. 3). Exposure to concentrations ranging from 0.5 to $2 \mathrm{mg} \mathrm{l}^{-1}$ PAA reduced the vitality of the tomonts and impaired theront development. Similar to the previous experiment of the present study, a doseresponse relationship was observed. The effect of PAA is particularly evident before the trophonts finish developing the cyst wall. However, some of the literature suggests that the development of vital theronts is not necessarily linked with the development of a cyst wall (Ewing et al. 1983, Aihua \& Buchmann 2001). The present study was not designed to differentiate between PAA preventing the tomonts from reaching the encysted stage and PAA reducing survival rate of the tomonts or tomites within. 
The third experiment was designed to determine the effect of PAA toxicity on age of tomonts and on exposure time. Age of the parasites clearly had an influence on PAA toxicity because of the development of the cyst wall. In contrast to the experiment where concentrations of 0.5 to $3.0 \mathrm{mg} \mathrm{l}^{-1}$ PAA were given at $2.5 \mathrm{~h}$ and showed distinct toxic effects (Fig. 3), the same concentrations were ineffective on all tomonts (presumably encysted) treated $24 \mathrm{~h}$ after removing them from the fish (Fig. 4). Extending the exposure time to $4 \mathrm{~h}$ had no significant effect on the amount of theronts produced by the tomonts. Microscopic examination indicated that $24 \mathrm{~h}$ after the start of the experiment, tomonts had developed a cyst wall, which probably protected the parasites from PAA exposure in concentrations up to $3 \mathrm{mg} \mathrm{l}^{-1}$.

The number of released theronts was not reduced by the PAA exposure when tomonts were protected by encystment. Considerably higher concentrations or extended exposure times will be necessary to kill encysted Ichthyophthirius multifiliis. However, high PAA concentrations are particularly toxic to juvenile fish (Meinelt et al. 2007a,b), and such concentrations would not be practical for treating diseased fish; therefore, higher PAA concentrations were not investigated. It is possible that some fish species (and/or life stages) are more resistant to PAA than those tested.

The effects of PAA on Ichthyophthirius multifiliis tomont survival may be more severe if constant concentrations could be ensured. However, PAA degrades quickly in relation to water parameters. Reports on the effects of water parameters such as temperature, organic load or $\mathrm{pH}$ on PAA concentrations vary. Harakeh (1984) stated that temperature, organic matter and suspended solids had negligible effects on the virucidal efficacy of PAA. Kitis (2004) emphasised the instability of PAA; a $40 \%$ PAA solution loses 1 to $2 \%$ of its active ingredient per month. Furthermore, Kitis (2004) described higher instability of diluted PAA solutions; for example, a $1 \%$ solution loses half its strength through hydrolysis within $6 \mathrm{~d}$. Unpublished data from our lab indicate that $2 \mathrm{mg} \mathrm{l}^{-1}$ degraded to below detection limits in 2 to $4 \mathrm{~h}$ depending on water temperature and aeration. In addition to having toxic effects against I. multifiliis, PAA has also been shown to be effective against other external parasites. Weitkamp et al. (2007) were able to eliminate external parasites including Chilodonella sp., Trichodina sp., Gyrodactylus sp. and Epistylis sp. by applying $2.6 \mathrm{mg} \mathrm{l}^{-1} \mathrm{PAA} \mathrm{d}^{-1}$ for $3 \mathrm{~d}$.

Rintamäki-Kinnunen et al. (2005a,b) used PAA-containing products (Per Aqua and Desirox; both were reported to be combinations of $13 \%$ peracetic acid, $20 \%$ acetic acid and $20 \%$ hydrogen peroxide) as single substances and/or in combination with formalin to treat Ichthyophthirius multifiliis. They found a reduced parasite burden and a reduction of losses in salmon and trout stocks. They suggested that fish surviving the I. multifiliis-infestation had time to develop immunity against further infestations (Rintamäki-Kinnunen et al. 2005a,b).

The results of the present study suggest that treating Ichthyophthirius multifiliis with PAA will be effective on all free, non-encysted stages of the parasite prior to development of a cyst wall; toxicity to these mature stages will be evident in the number of newly released theronts. Based on the results of the present experiments, we suggest treating with concentrations between 2 and $3 \mathrm{mg} \mathrm{l}^{-1}$ PAA. Because the hatch of tomonts and theronts is not synchronous between all $I$. multifiliis on a fish, a constant concentration PAA-concentration on a long-term scale must be ensured while treating this parasite in practice. Treating fish with PAA should be carried out by applying the chemical under dynamic conditions to ensure reasonably constant exposure concentrations. Although PAA concentrations $<2 \mathrm{mg} \mathrm{l}^{-1}$ are highly effective to treat theronts (Meinelt et al. 2007a) and tomonts (present study), PAA should be applied at nominal concentrations of at least $2 \mathrm{mg} \mathrm{l}^{-1}$ because PAA is known to be unstable.

Acknowledgements. We thank the Schreiner-Foundation, Greppin, Germany, for funding this study. We also thank Dr. Jander \& Co. OHG and Zoo \& Angelcenter Goral GbR (Germany) for providing infected fish. A. Radomski and C. Ledbetter provided critical reviews of the manuscript. Mention of trade names or commercial products in this article is solely for the purpose of providing specific information and does not imply recommendation or endorsement by the US Department of Agriculture.

\section{LITERATURE CITED}

Aihua L, Buchmann K (2001) Temperature- and salinitydependent development of a Nordic strain of Ichthyophthirius multifiliis from rainbow trout. J Appl Ichthyol $17: 273-276$

Amlacher E (1961) Die Wirkung des Malachitgrüns auf Fische, Fischparasiten (Ichthyophthirius, Trichodina), Kleinkrebse und Wasserpflanzen. Dtsch Fisch Z 8:12-15

Beckert H, Allison R (1964) Some host responses of white catfish to Ichthyophthirius multifiliis, Fouquet. Proc Southeast Assoc Game Fish Comm 18:438-441

Ewing MS, Kocan KM, Ewing SA (1983) Ichthyophthirius multifiliis: morphology of the cyst wall. Trans Am Microsc Soc 102:122-128

Goodwin AE, Straus DL (2006) Solid and liquid formulations of copper sulfate: efficacy at high and low alkalinities. N Am J Aquac 68:359-363

> Harakeh MS (1984) Inactivation of enteroviruses, rotaviruses and bacteriophages by peracetic acid in a municipal sewage effluent. FEMS Microbiol Lett 23:27-30

International Organization for Standardization (1996) DIN EN ISO 7346-3. Water quality. Determination of the acute lethal toxicity of substances to a freshwater fish Brachydanio rerio Hamilton-Buchanan (Teleostei, Cyprinidae), Part 3. Flow-through method. Beuth Verlag, Berlin 
Kitis M (2004) Disinfection of wastewater with peracetic acid: a review. Environ Int 30:47-55

Lom J, Dyková I (1992) Ciliates (Phylum Ciliophora Doflein, 1901). In: Protozoan parasites of fishes. Developments in aquaculture and fisheries science series, Vol 26. Elsevier Science Publishers B.V., Amsterdam, p 237-288

MacLennan RF (1937) Growth in the ciliate Ichthyophthirius multifiliis. I. Maturity and encystment. J Exp Zool 76:423-440

Matthews RA (2005) Ichthyophthirius multifiliis Fouquet and ichthyophthiriosis in freshwater teleosts. Adv Parasitol 59:159-241

Meinelt T, Phan TM, Stüber A, Bräunig I (2004) Wofasteril ${ }^{\circledR}$ und Wofasteril E250 zur Bekämpfung von Fischschimmel — erste Erfahrungen. Fisch Teichwirt 11:888-890

Meinelt T, Staaks G, Kunze K, Stüber A, Richert I (2005) Behandlung einer unspezifischen Mykose mit Peressigsäure (Wofasteril ${ }^{\circledR}$ E400) bei der Aufzucht der kleinen Maräne (Coregonus albula). Fisch Teichwirt 56:411

Meinelt T, Stüber A, Bräunig I (2006) Weitere Ergebnisse bei der Anwendung von Peressigsäure (Wofasteril E400 und Wofasteril E250) zur Bekämpfung von Fischschimmel (Saprolegnia parasitica) - erste Erfahrungen bei der Erbrütung von Regenbogenforellen. Fisch Teichwirt $1: 12-14$

Meinelt T, Staaks J, Staaks G, Stüber A, Bräunig I (2007a) Antiparasitäre Effekte von Peressigsäure (PES) gegen infektiöse Stadien (Theronten) der Weißpünktchenkrankheit, Ichthyophthirius multifiliis, in vitro. Dtsch Tierärztl Wochenschr 114:383-386 (in German with English summary)

Meinelt T, Richert I, Stüber A, Bräunig I (2007b) Einsatz von Peressigsäure zur Behandlung juveniler Zander (Sander lucioperca) bei Ichthyophthirius multifiliis-Befall. Dtsch Tierärztl Wochenschr 114:244-251 (in German with English summary)

Editorial responsibility: Dieter Steinhagen, Hannover, Germany
Nigrelli RF, Pokorny KS, Ruggieri GD (1976) Notes on Ichthyophthirius multifiliis, a ciliate parasitic on freshwater fishes, with some remarks on possible physiological races and species. Trans Am Microsc Soc 95:607-613

Rintamäki-Kinnunen P, Rahkonen M, Mannermaa-Keränen AL, Suomalainen LR, Mykrä H, Valtonen ET (2005a) Treatment of ichthyophthiriasis after malachite green. I. Concrete tanks at salmonid farms. Dis Aquat Org 64:69-76

Rintamäki-Kinnunen P, Rahkonen M, Mykrä H, Valtonen ET (2005b) Treatment of ichthyophthiriasis after malachite green. II. Earth ponds at salmonid farms. Dis Aquat Org 66:15-20

Schäperclaus W (1991) Prophylaxis and therapy of fish diseases. In: Schäperclaus W, Kulow H, Schreckenbach K (eds) Fish diseases. US Department of the Interior and the National Science Foundation, Washington, DC, Amerind Publishing, New Delhi, p 178-296

Straus DL, Griffin BR (2001) Prevention of an initial infestation of Ichthyophthirius multifiliis in channel catfish and blue tilapia by potassium permanganate treatment. N Am J Aquac 63:11-16

Straus DL, Meinelt T (2009) Acute toxicity of peracetic acid (PAA) formulations to Ichthyophthirius multifiliis theronts. Parasitol Res 104:1237-1241

Wahli T, Schmitt M, Meier W (1993) Evaluation of alternatives to malachite green oxalate as a therapeutant for ichthyophthiriosis in rainbow trout (Oncorhynchus mykiss). J Appl Ichthyol 9:237-249

Weitkamp H, Meinelt T, Bräunig I, Staaks J, Jander G (2007) Einsatz von Peressigsäure bei Fisch-Ektoparasitosen. In: Wahli T, Segner H, Schmidt-Posthaus H, Bernet D (eds) Tagungsband XI. Gemeinschaftstagung der Deutschen, der Österreichischen und der Schweizer Sektion der European Association of Fish Pathologists (EAFP). EAFP, Murten, p 1-21

Submitted: April 1, 2009; Accepted: June 24, 2009 Proofs received from author(s): August 31, 2009 